\title{
SHALLOW RIGHTS REVERSION: UNCERTAINTY AND DISPUTES
}

\author{
ALLAN INGELSON* AND WILL RANDALL ${ }^{* *}$
}

To encourage shallow gas production from up-hole non-producing zones on provincial lands and increase Crown royalty revenues, the Government of Alberta has adopted a shallow rights reversion (SRR) scheme for oil and gas mineral rights holders. Under SRR the rights to natural gas above the top of the shallowest productive zone are to be severed at the time of lease continuation and revert to the Crown, but the rights from the top of the shallowest productive zone to the base of the deepest productive zone will continue to be held by the Crown lessee.

In 2007 the British Columbia government amended the Petroleum and Natural Gas Act to establish a zone specific retention (ZSR) scheme. Under the ZSR system the Crown lessee need only establish the mere presence of oil or gas in a standard Zone Designation layer in order to continue the lease.

Unlike British Columbia, the SRR system in Alberta applies to all existing Crown leases, and is therefore more controversial than the ZSR regime. In April 2011, Alberta Energy intends to start serving SRR notices. The department has recently changed its policy regarding the consolidation of petroleum and natural gas agreements. The more complicated SRR system, which facilitates an increased number of oil and gas developers, may prompt additional trespass and commingling disputes.
Afin d'encourager la production de gaz à faible profondeur provenant de zones non productrices de foration montante sur les terres provinciales et de faire hausser les revenus provenant de redevances à la Couronne, le gouvernement de l'Alberta a adopté un mode de transfert des droits de production à faible profondeur pour les détenteurs de droits miniers pour le pétrole et le gaz. En vertu de ce régime, les droits au gaz naturel qui se trouve sur le dessus de la zone productive la moins basse sont coupés à la reconduction du bail et transférés à la Couronne; or, le détenteur du bail conserve les droits relatifs à la partie supérieure de la zone productive la moins basse jusqu'à la base de la zone productive la plus profonde.

En 2007, le gouvernement de la ColombieBritannique a modifié la Petroleum and Natural Gas Act, la loi sur le pétrole et le gaz naturel, pour établir un régime de zone de rétention spécifique. En vertu de ce régime, le détenteur d'un bail de la Couronne doit simplement établir la présence de pétrole ou de gaz dans une couche d'une zone de désignation standard pour maintenir le bail.

Contrairement à la Colombie-Britannique, le régime albertain vaut pour tous les baux existants de la Couronne et, par conséquent, soulève une plus grande controverse que le régime de la province voisine. En avril 2011, Alberta Energy compte commencer à signifier des avis selon le nouveau régime. Le ministère a changé sa politique en matière de consolidation des ententes sur le pétrole et le gaz naturel. Le régime albertain étant plus compliqué et facilitant un plus grand nombre d'agents de développement pétroliers et gaziers, peut occasionner des conflits additionnels relatifs aux intrusions et aux mélanges.

\section{TABLE OF CONTENTS}

I. INTRODUCTION . . . . . . . . . . . . . . . . . . . . 398

II. DEEP RightS REVERSION $\ldots \ldots \ldots \ldots \ldots \ldots \ldots \ldots \ldots \ldots \ldots \ldots . \ldots \ldots$

III. ZONE SPECIFIC RETENTION IN BRITISH COLUMBiA . . . . . . . . . . . . . 402

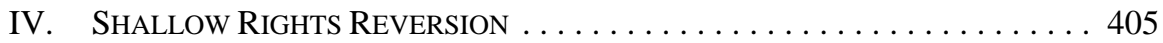

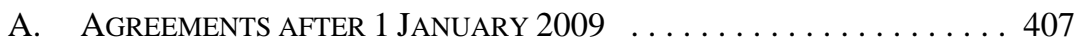

B. AGREEMENTS CONTINUED BEFORE 1 JANUARY 2009 . . . . . . . . . 408

** Associate Professor, Faculty of Law, University of Calgary, Member of the Law Society of Alberta.

B.Sc., J.D., LL.M., Member of the Texas Bar. We would like thank David Percy, Q.C., Borden Ladner Gervais Chair in Energy Law and Policy, Faculty of Law, University of Alberta; Denis Eisner, Devon Energy; and Rusty Miller, Ogilvy Renault LLP for their comments and suggestions. 
C. EXISTing AgreEMENTS (CONTINUED AFTER 1 JANUARY 2009) . . . 408

V. Commingling .......................... 409

A. CONSOLIDATION OF AgREEMENTS . . . . . . . . . . . . . . . . 410

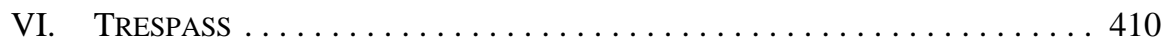

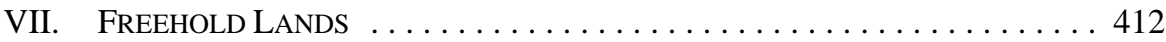

VIII. MinERAL RIGHTS EXPROPRIATION WithOUT COMPENSATION? . . . . . 412

IX. Cumulative ENVIRONMENTAL EFFECTS . . . . . . . . . . . . . . 415

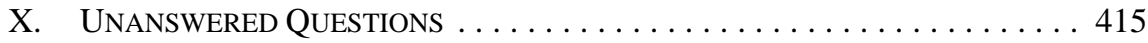

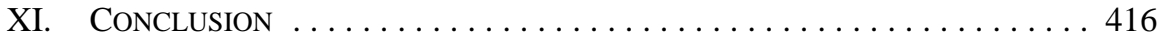

\section{INTRODUCTION}

The emerging shallow rights reversion (SRR) regime is an extension of the deep rights reversion (DRR) system adopted by the Government of Alberta in $1976 .{ }^{1}$ SRR means that "the petroleum and natural gas rights above the top of the shallowest production zone in an agreement will be severed from the agreement at continuation."2 The original Crown lessee will retain the rights to producing zones but lose the rights to the shallowest non-producing zone when it reverts back to the government, and may be made available for resale. ${ }^{3}$ This article examines the issues that can arise from the adoption of the SRR regime. We will consider SRR in the context of the experience with DRR, and approaches to the severance of mineral rights in British Columbia and the United States.

\section{DEEP RIGHTS REVERSION}

Severance of the mineral rights to different zones under the Mines and Minerals Act ${ }^{4}$ is not a new concept in Alberta. In 1952, the Alberta government introduced natural gas leases with 21-year terms that conveyed the rights to specific zones that had been "proven in paying quantity." "The zones were defined by zone designations (ZD). ${ }^{6}$ Subsequently, the Alberta government implemented a DRR scheme under which non-producing zones have reverted to the Crown for disposition to interested mineral developers. ${ }^{7}$ The regulatory experience with DRR will provide insight as to the types of issues that can arise with SRR.

1 See Robert T. Booth \& Robert P. Desbarats, "Recent Developments in the Law of Interest to Oil and Gas Lawyers” (1982) 20 Alta. L. Rev. 179 at 222-23; Donald MacDiarmid, Patrick Maguire \& Shawn Denstedt, "Recent Legislative and Regulatory Developments of Interest to Oil and Gas Lawyers" (1994) 32 Alta. L. Rev. 375; Francine Swanson, Michael Hurst \& Edward Rowe, "Recent Judicial Developments of Interest to Oil and Gas Lawyers” (1997) 35 Alta. L. Rev. 413.

2 Government of Alberta, "Shallow Rights Reversion Frequently Asked Questions,” online: Alberta Energy <http://www.energy.gov.ab.ca/Tenure/912.asp> [“SRR Frequently Asked Questions”].

3 Government of Alberta, "Shallow Rights Reversion," online: Alberta Energy <http://www.energy. gov.ab.ca/Tenure/603.asp>. "Zone” refers to "a stratum or series of strata considered by the Minister [of Energy and Natural Resources] to be a zone" for the purposes of the Petroleum and Natural Gas Tenure Regulation, Alta. Reg. 263/97, s. 1(x).

$4 \quad$ R.S.A. 2000, c. M-17, s. 82(2) [MMA].

$5 \quad$ See Alberta Energy, Information Letter 98-14, “Application of Zone Designations (ZDs) and Deeper Rights Reversion Zone Designations (DRRZDs) for the Sale, Drilling and Production of Split (Shallow/Deeper) and Excepted Petroleum and/or Natural Gas Rights” (29 April 1998) at Appendix I [Information Letter 98-14].

$6 \quad$ Ibid. at 4.

$7 \quad$ The Mines and Minerals Amendment Act, 1976, S.A. 1976, c. 33, s. 9, amending The Mines and Minerals Act, R.S.A. 1970, c. 238, Part 5. 
Effective December 1981, deeper rights reversion zone designations (DRRZD) were created to describe the deepest rights retained in five-year Crown leases that expired after the DRR scheme was implemented. ${ }^{8}$ On 1 January 1983, approximately 13,000 continued leases with terms of ten or 21 years "were severed to remove the deeper rights, using a DRRZD to describe the base of the deepest productive zone in each [Crown] agreement." In the case of DRR, the zone below the deepest productive zone reverts to the Crown, "so that the rights earned by [the] oil company-lessee were restricted to those geological zones above the base of the deepest geological formation proven capable of production from the lease."10 Immediately before and shortly after the DRR scheme was adopted, some Crown lessees suggested that the Alberta government had violated the "sanctity of contract" by altering the mineral rights agreements and "taking away" potentially valuable rights. However, there were no reported lawsuits based on takings or expropriation of the oil and gas rights by the Crown, ${ }^{11}$ as the success of such litigation was uncertain and the focus at that time was to negotiate the resolution of mineral ownership disputes with the Alberta government. ${ }^{12}$ Much of the oil and gas industry eventually viewed the DRR scheme as a positive development, because a limited number of oil or gas developers could not "monopolize" the development of potentially productive zones. ${ }^{13}$

The Government of Saskatchewan followed the Alberta government's lead and amended The Crown Minerals Act ${ }^{14}$ to provide for deep rights reversion. ${ }^{15}$ In April 1998, the Saskatchewan government announced that it had implemented a "new deep oil and gas rights reversion program" to "maximize resource recovery." 16 The government indicated that "it would amend The Crown Minerals Act to include deep rights reversion provisions similar to those already in place in Alberta," ${ }^{17}$ and cited the following reasons for adopting a scheme like the one in Alberta:

That is because ... relatively unexplored and technological advancements have made it easier for industry to explore, develop and produce oil and gas from those depths. But this is also a prudent move to maximize revenues from our oil and gas resources. We will realize additional revenues through Crown land sales, and ultimately, incremental royalties from any new oil or gas discovered in these newly acquired lands. ${ }^{18}$

Similar reasons have been advanced for adopting the SRR scheme in Alberta. In the last ten years, horizontal drilling as a technological advance has facilitated economic development of methane from shallow coals in some areas of the province. The Alberta

See Information Letter 98-14, supra note 5 at Appendix I; ERCB, Bulletin 2008-13, "Revisions to Coding and Naming Conventions for Formations and Pools in Alberta” (27 March 2008). All ERCB documents can be found online: ERCB <http://www.ercb.ca/portal/server.pt?>. Information Letter 98-14, ibid.

Freehold Owners Association, “Deep Rights Reversion,” online: Freehold Owners Association $<$ http://www.fhoa.ca/deeprts.htm>.

Ibid.

A search of Alberta reported decisions since 1976 indicates that there has been no expropriation decision made against the Alberta government in regards to DRR.

Freehold Owners Association, supra note 10.

S.S. 1984-85-86, c. C-50.2.

See MacDiarmid, Maguire \& Denstedt, supra note 1 at 394.

Government of Saskatchewan, News Release, "New Deep Oil and Gas Rights Reversion Program Helps Maximize Resource Recovery” (1 April 1998), online: Government of Saskatchewan <http://www.gov. sk.ca/news>.

Ibid.

Ibid. 
government has recognized that unconventional gas development is gaining prominence in the Western Canadian Sedimentary Basin, with 60 percent of industry activity focused on unconventional gas. ${ }^{19}$ Unconventional gas includes coalbed methane (CBM), gas from shale, ${ }^{20}$ and tight gas. ${ }^{21}$ The Energy Resources Conservation Board (ERCB) has estimated that there are 39 trillion cubic feet (Tcf) of established conventional natural gas reserves in the province. ${ }^{22}$ Alberta is the first province with commercial CBM production and continues to be the largest producer in Canada. ${ }^{23} \mathrm{CBM}$ is playing an increasingly important role in the volume of natural gas produced in the province. ${ }^{24}$ The Alberta Geological Survey has estimated there may be 500 Tcf of CBM in Alberta, significantly more than the 87 Tcf of potential conventional natural gas remaining in the province. ${ }^{25}$ In 2001 , the first commercial Canadian CBM production was reported in Alberta from the Horseshoe Canyon coals and in 2008 commercial production from the Mannville coals, which are estimated to contain a much larger volume of methane, was announced. ${ }^{26}$ The amount of unconventional gas that may be economically produced from Crown lands under SRR is uncertain. However, what is clear is that the majority of new gas wells that are currently being drilled target unconventional gas, and this trend will continue in Alberta as production from conventional gas reservoirs declines. ${ }^{27}$

As was the case with DRR, the reaction of oil and gas producers to the SRR scheme has been mixed. Some oil and gas companies interested in developing CBM have complained that they are unable to develop shallow gas in the province due to the lack of Crown land on which they might otherwise explore for shallow gas, and have welcomed the new scheme. Other oil and gas producers have objected to SRR in light of the potential problems surrounding commingling, pipeline and facility utilization, and the notion that the Crown has expropriated their mineral rights without compensation. ${ }^{28}$ Notwithstanding a lack of consensus in the oil and gas industry about SRR, increased CBM development has prompted

See Dave Russum, “Unconventional Gas in North America — the massive paradigm shift” (Presentation to the Petroleum History Society, Calgary Petroleum Club, 24 February 2010) at 22, online: AJM Petroleum Consultants <http://www.ajmpc.com/uploads/files/presentations/ajm_pres_ 2010_02_PHSUncnvntlGas.pdf>.

20 Unconventional Gas Resources, “What is Unconventional Gas?,” online: Unconventional Gas Resources $<$ http://www.ugresources.com/unconventionalgas.html >:

Gas shales is natural gas stored in organic rich rocks such as dark-coloured shale; wherein the recoverable gas is interbedded with layers of shaley siltstone and sandstone. Gas shales are formed from the mud of shallow seas that existed about 350 million years ago. Shale is a very fine-grained sedimentary rock that may be easily broken into thin layers, and though it is a very soft rock, it does not disintegrate when it becomes wet. These shales often contain natural gas, when two thick black shale deposits "sandwich" a thinner area of shale. Shale gas may also be produced through naturally-occurring fractures in shale, which allows gas to flow through the rock.

Ibid.: "Tight Gas is gas that is 'stuck' in a very tight formation underground, stored within low porosity and low permeability rock formations. A great deal of effort has to be put into extracting gas from a tight formation, such as fracturing and acidizing. Tight gas makes up a significant portion of North America's natural gas resource base.”

See Government of Alberta, “Natural Gas — Statistics,” online: Alberta Energy < http://www.energy. gov.ab.ca/NaturalGas/727.asp>.

In 2009, British Columbia became the second province in Canada with commercial CBM production. Unconventional Gas Resources, supra note 20.

Government of Alberta, “About Coalbed Methane,” online: Alberta Energy < http://www.energy.gov.ab. ca/NaturalGas/754.asp\#>; “Natural Gas — Statistics,” supra note 22.

Government of Alberta, “Coalbed Methane Development” (11 March 2009), online: Alberta Energy $<$ http://www.energy.gov.ab.ca/NaturalGas/753.asp>.

Russum, supra note 19 at 13, 22.

See Paige Ainslie, “Deep Concerns About Shallow Rights Reversion”Energy @ Gowlings 7:3 (20 February 2009), online: Gowling Lafleur Henderson LLP <http://www.gowlings.com/resources/ enewsletters/energy/Htmfiles/V7N03_20090220.en.html\#b>. 
the Alberta government to facilitate access to Crown mineral rights to more oil and gas exploration companies through SRR. ${ }^{29}$ By severing non-producing zones, the Alberta government intends to encourage drilling and production in these shallow zones. As with DRR, the government has implemented SRR to increase Crown oil and gas revenues from additional development on Crown lands.

However, with an increased number of players holding the rights to different zones, there is increased potential for disputes. Xerex Exploration Ltd. v. Petro-Canada ${ }^{30}$ is one example of a dispute between the holders of shallow and deep rights. In Xerex, Petro-Canada Oil and Gas (Petro-Canada) held the shallow rights and Xerex Exploration Ltd. (Xerex) held the deep rights. ${ }^{31}$ With leave from the Alberta Energy and Utilities Board, Petro-Canada drilled $15 \mathrm{~m}$ into a deep rights zone to identify the boundaries of a potentially productive "over-hole" allowance. Petro-Canada promptly contacted Xerex with an offer to acquire the deep rights, but the Petro-Canada landman misrepresented the company's trespass into the deep rights zone held by Xerex. ${ }^{32}$ The Court of Appeal concluded that during the mineral rights negotiations the Xerex representative asked the Petro-Canada landman whether Petro-Canada had drilled into the deep rights zone and the answer "No" from the Petro-Canada landman amounted to a misrepresentation, as the company had indeed drilled into the zone. ${ }^{33}$ Several days after the telephone conversation, Petro-Canada successfully acquired the deep rights from Xerex for a 3 percent gross overriding royalty. ${ }^{34}$ Petro-Canada successfully developed a well, but did not pay a royalty to Xerex; the company sued Petro-Canada for misrepresentation. ${ }^{35}$ The trial judge ruled in favour of Xerex; Petro-Canada appealed to the Alberta Court of Appeal. Alberta's highest court held that Petro-Canada had misrepresented the facts and was in the position of a fiduciary toward Xerex. The Court concluded that the purpose of the over-hole allowance was to allow Petro-Canada to explore its shallow rights, rather than to gain information on the deep rights held by the other party oil company. The over-hole allowance into the deep rights placed Xerex in a vulnerable position, and PetroCanada had a fiduciary duty to disclose its information on the hydrocarbons in the deep rights zone during the negotiations. ${ }^{36}$

As is discussed in one commentary on the Xerex decision, ${ }^{37}$ the Alberta Court of Appeal noted that there are several unanswered questions about the obligation of shallow rights holders, including whether there is "a general duty on the shallow-rights holder to disclose information when nothing particularly useful is observed or if the shallow rights holder does not intend to make use of the information obtained."38 The question remains as to whether

Angela St. Jean, “Alberta Shallow Rights Reversion” The Negotiator (January 2009) 4, online: Canadian Association of Petroleum Landmen <http://landman.ca/publications/Negotiator/2009/jan/jan09_ layout.pdf>.

302005 ABCA 224, 367 A.R. 201 [Xerex]. See John Wilson, “Court of Appeal Imposes Obligations on Shallow Rights Holders” Energy Matters (January 2006) 1, online: Burnet, Duckworth \& Palmer LLP <http://www.bdplaw.com/titanweb/bdp/bdpwebsite.nsf/AllDoc/6C4A1D2EBBB384BF87257 10E007272C8/\$File/BDP\%20Energy\%20NL\%20Jan.\%2006.pdf>. Wilson, ibid. at 1.

Ibid. at 2.

Xerex, supra note 30 at para. 53.

Ibid. at para. 24.

Ibid. at para. 34 .

Ibid. at paras. 77-82.

See Wilson, supra note 30.

Ibid. at 2. 
a shallow rights holder in Petro-Canada's position could merely "wait until the deep-rights licence expired and then acquire the licence for itself, without making disclosure." ${ }^{39}$ With more oil and gas companies developing natural gas under the SRR regime there is the potential for additional trespass disputes.

In the context of negotiating and drafting farm-in and farm-out agreements to facilitate exploration of multiple zones (including shallow rights zones) in the future, unanswered questions remain as to the obligations on either party to report the presence of hydrocarbons to the other party holding the rights to a different zone, the type and extent of the information to be disclosed, and whether there is an obligation to maintain the confidentiality of some or all of the information when there are several zones and multiple parties involved. The uncertainty surrounding these issues may well prompt additional disputes in what is a complicated situation. The added layer of complexity should prompt careful consideration of these issues by counsel when drafting agreements.

In 2007, the British Columbia government introduced a zone specific retention (ZSR) system for Crown oil and gas rights. ${ }^{40}$ We will examine the similarities and differences between the British Columbia and Alberta rights severance regimes to develop some insight as to the issues that oil and gas developers can anticipate with SRR.

\section{ZONE SPECIFIC RETENTION IN BRITISH COLUMBIA}

The Government of British Columbia began discussions with the oil and gas industry in the 1990s regarding its intention to retain the oil and gas rights to specific zones covered under existing leases. ${ }^{41}$ The goal of the government was to secure the return of all oil or gas bearing zones on Crown lands in order to facilitate hydrocarbon production from those zones and increase Crown royalty revenues. The results of discussions with the oil and gas industry were mixed and the Canadian Association of Petroleum Producers (CAPP) recommended that the government not implement ZSR. ${ }^{42}$ However, the government implemented the scheme as indicated in ss. 59 and 59.1 of the Petroleum and Natural Gas Act. ${ }^{43}$ The legislation provides for stratigraphic reversion as follows:

59(1) If a lease or part of a lease is continued under section 58 (3) (a) or (b), the petroleum and natural gas rights granted by the lease that are stratigraphically outside the zone or zones known by the director to be capable of production in the lease or part of the lease revert to the government when that continuation begins.

(2) If a lease or part of a lease is continued under section 58 (3) (c) or (d), the petroleum and natural gas rights not continued revert to the government when that continuation begins, subject to the lease or part

$39 \quad$ Ibid

$40 \quad$ Patrick O’Rourke, “Amendments to Zone Specific Retention in B.C.” The Negotiator (October 2007) 23, online: Canadian Association of Petroleum Landmen <http://www.landman.ca/publications/ Negotiator/2007/oct/oct07_layout.pdf>.

41 Dennis Eisner, "The Ugly, the Bad and the Good: Recent Regulatory Issues Relating to Mineral Land" (Natural Resources Law Lecture, delivered at the Faculty of Law, University of Calgary, 12 November 2009) [unpublished].

42 Ibid.

$43 \quad$ R.S.B.C. 1996 , с. 361. 
of the lease being continued under section 58 (3) (a) or (b) and the application of subsection (1) of this section.

59.1(1) Despite section 59, this section continues to apply to a lease

(a) that was issued under section 64 or 71 before March 29, 2007,

(b) that is issued from a permit or a drilling licence that was issued before March 29, 2007, if the location of the lease is within or coincides with the location of the permit or the drilling licence, or

(c) that is issued under section 64 from a lease described in paragraph (a) or (b) of this subsection.

(2) If, at the relevant time referred to in this subsection, a lease is continued under section 58, the petroleum and natural gas rights granted by the lease that are stratigraphically below the base of the deepest zone known by the director to be capable of production in the lease or the part of the lease revert to the government and do not continue under the lease

(a) in the case of a 5 year lease, on the expiration of its initial term,

(b) in the case of a 10 year lease, on the expiration of its initial term,

(c) in the case of a 10 year lease that is a renewal of a 21 year lease, on the expiration of its term, and

(d) in the case of a 21 year lease, on the expiration of its initial term.

(3) If, at the relevant time referred to in subsection (2), all or part of the lease is being continued under section 61 or 62 , subsection (2) applies to that lease for the part so continued on the date on which the continuation ceases under section 61 or 62 , as the case may be. ${ }^{44}$

ZSR does not affect lease agreements made prior to 29 March 2007. Agreements made after that date are subject to ZSR at the dates of continuation, which are 2012 or 2017 depending on the terms of the lease. To continue the lease at the expiry of the term, the British Columbia Crown lessee must show that there is oil or gas on the lease. ZSR employs a zone designation system, created by the province in 1998, to administer the stratigraphic rights reversion system. In light of the importance of security of tenure and a stable Crown oil and gas rights regime to promote increased investment in the much smaller British Columbia industry than in Alberta, the interprovincial competition for oil and gas development capital amongst the western provinces, and the lack of CBM production from shallow zones in British Columbia, we submit there was no impetus to create ZSR until the late 1990s. 
Unlike SRR in Alberta, ZSR applies to any zone that is not producing hydrocarbons, rather than just the shallowest zone. The ZSR regime allows for lease continuation based on the Crown lessee testing and verifying the existence of an oil or gas pool. Any oil or gas pool that exists in any zone qualifies for lease continuation if the relevant engineering or geophysical studies verify the existence of a pool. The British Columbia legislation does not require lessees to complete and flow each zone in order to secure a lease continuation. ${ }^{45}$ The British Columbia government has prevented some conflicts between Crown lessees by selecting clear geographic correlations to differentiate zones. ${ }^{46}$

The British Columbia scheme appears to be more favourable to Crown lessees than does the Alberta SRR scheme, as an oil and gas company only needs to show the presence of oil or gas to continue the Crown lease. The British Columbia Crown lessee does not have to explore for and produce oil or gas to avoid reversion of the rights to a specific zone. Arguably, the minimal expectation in British Columbia undermines the objective of increased oil and gas production, as the Crown lessee need only show the presence of an oil or gas pool in a zone to continue the rights to that zone.

A fundamental difference between the SRR regime in Alberta and the ZSR system is that the British Columbia regime applies only to Crown oil and gas leases issued after 29 March 2007. As SRR applies to all Crown leases in Alberta, the system is more controversial than its British Columbia counterpart. One explanation as to why the Alberta government did not adopt the British Columbia government's approach of applying zone reversion only to more recent Crown leases is that a much larger proportion of Crown land in Alberta is under lease ${ }^{47}$ than in British Columbia, and there is less unexplored Crown land in Alberta. ${ }^{48}$

Notwithstanding that the British Columbia government created the ZSR system before the SRR system in Alberta, as ZSR rights reversions will not commence until 2012, there is a lack of Crown lease administrative experience in British Columbia that might be useful in anticipating and managing the issues that may arise in Alberta in 2011, when the government commences serving notices under the SRR system.

In light of the limited experience with oil and gas rights reversion in British Columbia, we will briefly consider the longer experience in several U.S. states with the severance of mineral rights meant to encourage exploration and production from non-producing areas. In several U.S. states, a clause known as the Pugh clause has been incorporated into oil and gas leases. Raymond Mitchell, a Texas attorney, alludes to the effect of the clause on oil and gas exploration and production:

Without the Pugh Clause, if [a] lease covered 600 acres and the petroleum company only put 20 acres in a pooled unit for a producing well, the lease would remain in effect as to the 580 acres not being used as well as the 20 acres in the unit. Even though [the lessor is] receiving no production (and thus no profit) from the 580 acres, they would remain tied-up by the lease indefinitely. With the Pugh Clause, the 580 acres would be released from the lease at the end of the primary term. [The lessor] would continue to receive royalties

O’Rourke, supra note 40 at 24.

Ibid. at 26.

Eisner, supra note 41.

Ibid. 
from the production from the 20 acres, and the 580 acres would be available to lease to another company when one comes along. 49

The Pugh clause provides that when the primary lease term ends, all rights of the lessee to non-producing lands shall also end. ${ }^{50}$ The lessee may undertake testing to avoid the reversion of the unused portion of the land to the owner of the mineral estate. ${ }^{51}$ Producing land generally remains in the lease as long as some profit is realized. One type of Pugh clause, a vertical depth severance clause, ${ }^{52}$ has been used for decades in several U.S. states to encourage increased exploration and production; the same objective that the Alberta government intends to achieve with SRR.

\section{SHALLOW RightS REVERSION}

In 2007, the Alberta government undertook a review of the Crown's share of oil and gas royalty revenues to evaluate whether the government take from oil and gas production on Crown lands was appropriate. The SRR regime is one outcome of the royalty review process. The Tenure Industry Advisory Committee (TIAC) to the Alberta government served as a joint government-industry panel to advise the government on the modification of existing agreements with respect to timing and notification to lessees. Members of TIAC include CAPP, the Small Explorers and Producers Association of Canada (SEPAC), the Canadian Association of Petroleum Landmen (CAPL), the Canadian Association of Petroleum Land Administration, the ERCB, the Alberta Department of Sustainable Resource Development and Environment, the Department of Energy, and the Farmer's Advocate. Industry groups participated, although only SEPAC went on record to support SRR. ${ }^{53}$ Other industry groups opposed SRR as being heavy-handed and amounting to an expropriation of long-held contractual rights. Notwithstanding the mixed industry reaction, the government will commence serving notices under the SRR system in April 2011. ${ }^{54}$

As noted above, SRR is an extension of the DRR framework that has been in place for several decades. Section 18(1) of the Petroleum and Natural Gas Tenure Regulation provides for the rights severance under DRR as follows:

The Minister may give a lessee written notice in accordance with this section if

(a) the lease is continued pursuant to section 15(1)(a) or (e) as to all or any part of its location in a spacing unit and the Minister considers that the deepest productive zone in the spacing unit is then no longer productive,

49 “The Pugh Clause,” online: The Law Offices of Raymond R. Mitchell <http://www.mitchelltexaslaw.com/subpage.html>.

Black's Law Dictionary, 8th ed., s.v. "Pugh clause.”

See O’Rourke, supra note 40 at 24; “The Pugh Clause,” supra note 49.

See e.g. "Vertical Depth Severance Clause," online: Network of Petroleum Landmen <http://www. landmen.net/ClausesForms/vertical_pugh.html>.

53 See Mike Byfield, "Mel Knight: Why Alberta Will Impose Shallow Rights Reversion” Oil \& Gas Inquirer (29 October 2007), online: Oil \& Gas Inquirer <http://www.oilandgasinquirer.com/ article.asp?article=magazine\%2F071029\%2FMAG2007_OT0001.html>.

54 Alberta Energy, Information Letter 2010-14, "Shallow Rights Reversion (SRR) Notices — Schedule for 2011 and 2012” (20 April 2010) at 1 [Information Letter 2010-14]. 
(b) the lease is continued pursuant to section 15(1)(b) as to all or part of its location in a spacing unit and the deepest productive zone in the spacing unit is then no longer subject to a unit agreement,

(c) the lease is continued pursuant to section 15(1) (c) as to all or part of its location in a Crown spacing unit and the freehold well concerned has, for a continuous 6-month period, ceased to produce petroleum or natural gas from the zone that is the same as the deepest productive zone in the Crown spacing unit, and the Minister considers the zone in the freehold spacing unit to be no longer productive, or

(d) the lease is continued pursuant to section 15(1)(d) as to all or part of the location in a spacing unit and the deepest productive zone in the spacing unit is then no longer subject to a gas storage agreement. ${ }^{55}$

Building upon its experience with DRR, the Alberta government is in the process of amending Crown documents to incorporate SRR and notices will be issued pursuant to s. 82 of the $M M A .{ }^{56}$ The Alberta Department of Energy (Alberta Energy) has indicated that it will phase in the reversion notices to Crown agreement holders, with initial notices being issued to the oldest Crown agreements. Parties holding petroleum and natural gas (P\&NG) agreements with general term dates of 1953 to 1958 will be served SRR notices in 2011, and those with term dates of 1958 to1962 will be served notices in 2012. ${ }^{57}$ As of 20 April 2010, Alberta Energy indicated that "P\&NG Agreements subject to Unit Agreements will be reviewed at a later date." 58 The notice will indicate what the shallowest productive zone is as determined by the Alberta government based on public records. The rights will be described based on zone designations created for the DRR system, and rely on DRRZDs outlined in Information Letter 98-14. ${ }^{59}$ Reversion of shallow rights will occur three years after the government has served notice on the lease representative.

Three time phases during which Crown agreements were issued have been selected by Alberta Energy to manage the transition to SRR. Agreements made prior to 1 January 2009 that have not been continued will be subject to notification of SRR after continuation under s. 15 of the Petroleum and Natural Gas Tenure Regulation. ${ }^{60}$

Supra note 3.

Supra note 4.

Information Letter 2010-14, supra note 54 at 2.

Ibid.

Supra note 5.

Supra note 3:

15(1) Subject to section 14 and subsections (2) and (3) of this section, the Minister, in accordance with this Regulation, shall approve the continuation of a lease after the expiration of its term to the extent that the location is within any or all of the following:

(a) the spacing unit for a well that is productive from a zone in the location;

(b) a spacing unit all or part of which is within the unit area of a unit agreement to which the lease is subject;

(c) a spacing unit adjoining the spacing unit for a freehold well if

(i) in accordance with this Regulation and before the expiry of the term of the lease, the lessee has notified the Minister in writing that the lessee elects to pay offset compensation in respect of the location or the part of the location within the spacing unit, and

(ii) offset compensation is being paid in respect of the location or the part of the location within the spacing unit;

(d) a spacing unit all or part of which is within the area of a gas storage agreement to which the lease is subject;

(e) a spacing unit all or part of which is productive from a zone in the location.

(2) The Minister's approval under subsection (1), in relation to a spacing unit containing the location or any part of the location, shall be granted down to the base of whichever of the zones described in the following clauses is stratigraphically the deepest in that spacing unit: 
For those agreements made prior to 1 January 2009 that have been continued, the government will serve notice that the shallow rights will revert in three years. ${ }^{61}$ Finally, for those leases made on or after 1 January 2009, the lease will be subject to SRR at continuation.

Alberta Energy intends to notify the lease representative on file in writing that the shallow rights will revert unless the lessee "proves up" the existence of oil or gas. To avoid reversion of the rights, a Crown lessee will have to undertake exploration of the zone to prove up the rights. This may be accomplished through the following methods:

(1) the use of geological mapping to prove up the shallowest zone;

(2) the use of unitized zones that include the shallow rights;

(3) making a payment of offset compensation; or

(4) by proving productivity with a successful gas test or by achieving production either by re-entering an existing wellbore or drilling a new well. ${ }^{62}$

It is very important that companies know "how the productive zones are defined geologically." ${ }^{\text {"Z }}$ Zones that are not severed at the time of a lease continuation will remain in the agreement for the original lessee.

\section{A. Agreements After 1 January 2009}

In the case of Crown agreements issued after 1 January 2009, the holder must prove up both the shallowest and deepest rights to secure continuation at the expiry of a primary term lease or intermediate term licence. ${ }^{64}$ A licensee or lessee may apply for continuation of the shallow and deep zones at any point in the notification year using the same continuation process that has always been in place in Alberta. ${ }^{65} \mathrm{SRR}$ will not affect an initial term licence, but once that licence is validated SRR will affect the licence at the expiry of the intermediate term. ${ }^{66}$ The terms of licences vary based on the region in which the lands covered by the

(a) the deepest zone from which the well is productive, if continuation is approved under subsection (1)(a) in relation to that spacing unit;

(b) the deepest zone that is subject to a unit agreement, where continuation is approved under subsection (1)(b) in relation to that spacing unit;

(c) the offset zone from which the freehold well is producing petroleum or natural gas, if continuation is approved under subsection (1)(c) in relation to that spacing unit;

(d) the deepest zone that is subject to a gas storage agreement, if continuation is approved under subsection (1)(d) in relation to that spacing unit;

(e) the deepest productive zone, if continuation is approved under subsection (1)(e) in relation to that spacing unit.

(3) If the Minister approves the continuation of a lease after the expiration of its term under section 16 as to all or part of the location, this section does not apply to the lease or to the part of the

location, as the case may be, while the lease is continued under section 16 . St. Jean, supra note 29 at 5 .

Ibid. at 6 .

Ralph Glass, “Shallow Rights Reversion - Headache or Opportunity?” F.Y.I.: Perspectives on Industry Issues (Winter 2008) at 1, online: AJM Petroleum Consultants <http://www.ajmpc.com/uploads/ files/fyi/ajm_FYI_2008_12.pdf >.

64 St. Jean, supra note 29 at 5.

65 Ibid.

66 Ibid. 
licence are located. In the Plains Region, the initial term is two years and, upon validation, the intermediate term is five years. ${ }^{67}$ In the Northern Region, the initial term is four years, and the intermediate term is five years. ${ }^{68}$ In the Foothills Region, the initial term is five years with an additional five-year intermediate term upon validation. ${ }^{69}$ Therefore, attention needs to paid to the term of the licence in order to avoid inadvertent reversion of the shallow rights.

\section{B. Agreements Continued Before 1 January 2009}

In regard to agreements continued before 1 January 2009, the province must notify the holder of the agreement of the new SRR scheme before the reversion of any rights. After the service of the notice, the holder has three years to prove up the zone to retain the shallow rights. ${ }^{70}$ There is no late application process to prove up the shallow rights, but an extension may be available under s. 82.1(6) of the MMA if drilling occurs in the three months prior to the end of the notice period. ${ }^{71}$ Approval of an extension is less likely if an agreement holder waits until the end of the notice period to prove up its rights. ${ }^{72}$ Finally, if the agreement holder does not prove up the rights, they will revert to the Crown. A decision regarding the reversion of a shallow zone to the Crown may be changed at the Minister of Energy's discretion upon payment of \$5,000 within 60 days of expiry. The Minister has broad discretion as to whether a reversal of a reversion may be granted. However, under s. 8(1)(e) of the $M M A$, the Minister may not grant an extension if the area has been leased. ${ }^{73}$ The Act does not specify the factors to be considered by the Minister when considering a request, but extenuating circumstances could arguably form the basis for the review of the decision to sever the rights. It is not clear what specific information would be required for an extension. The general principles of administrative law, including the rules of natural justice to provide for procedural fairness, would apply if the lessee challenges a decision.

\section{Existing Agreements (Continued After 1 JAnuARy 2009)}

The third phase applies to agreements in existence before 1 January 2009, but those that have not reached a date of continuation. In the case of an initial term licence, validation occurs without SRR, and leads to a five-year intermediate term after which SRR will apply. ${ }^{74}$ For a primary term lease or intermediate term licence, DRR occurs at continuation, and only then will the province serve an SRR notice. ${ }^{75}$

In light of the three-year notice period provided by the government, it would be prudent for the mineral rights holder to diligently conduct work during the notice period in order to

Petroleum and Natural Gas Tenure Regulation, supra note 3, ss. 5(1)(b), 6(1)(a).

Ibid., ss. 5(1)(b), 6(1)(b).

Ibid., ss. 5(1)(b), 6(1)(c).

Glass, supra note 63.

Supra note 4.

"SRR Frequently Asked Questions," supra note 2.

Supra note 4.

See Information Letter 2010-14, supra note 54 at 1; “Tenure Information Exchange” (Sponsored by Alberta Energy, CAPL, and the Canadian Association of Petroleum Land Administration, 22 April 2010), online: Alberta Energy < http://www.energy. alberta.ca/News/1028.asp>.

"Tenure Information Exchange," ibid. 
retain the rights. In a situation such as drilling over an expiry period, the mineral rights holder may request an extension. ${ }^{76}$

There is uncertainty about the issues that will arise as notices are served by Alberta Energy and implementation of the SRR system proceeds in 2011. However, commingling, agreement consolidation, trespass, freehold rights reversion, acreage reporting, and takings claims are some of the issues that may lead to disputes. As of the date of writing this article, some of these issues have been addressed by the Alberta government, others have not.

\section{Commingling}

Commingled gas is a "homogeneous mix of natural gas from various physical (or contractual) sources"77 that can include gas produced from several zones in one well bore. Commingling allows production from more than one zone, and therefore can maximize the rate of natural gas capture. The practice can reduce the surface footprint of the industry by reducing the number of wells to be drilled and required to produce gas economically. To avoid commingling disputes between gas producers, and in light of the anticipated increase in shallow gas production, in 2006 the ERCB provided some guidance as to the desired industry practices through documents including: commingling in development entities (DE), self-declared (SD) commingling, and applications in accordance with Directive 065: Resources Applications for Conventional Oil and Gas Reservoirs. ${ }^{78}$ The ERCB indicates that $\mathrm{DE}$ is "an entity consisting of multiple formations in a specific area described in an order of the ERCB, from which gas may be produced without segregation in the wellbore subject to certain criteria specified in section 3.051 of the Oil and Gas Conservation Regulations.”79 The regulator indicates that "[i]f ownership or royalty interests vary in intervals to be commingled, all parties must agree to the commingling before it occurs." ${ }^{\text {"0 }}$ Directive 062: Coalbed Methane Control Well Requirements and Related Matters requires that all licensees establish a control well within three km of the CBM pool to measure pressure, productivity, and gas content from the coal formation. ${ }^{81}$

In the case of DE, the ERCB requires applicants for commingling to proceed under a Directive 065 application where there is a water well within $600 \mathrm{~m}$ and the total depth is less than $25 \mathrm{~m}$ from the top of the pool; the commingling stream contains $\mathrm{H}_{2} \mathrm{~S}$; or production of the gas cap to an oil pool may impact recovery from the oil pool. ${ }^{82}$

$76 \quad$ Ibid.

77 Robert D. Bott, Our Petroleum Challenge: Sustainability into the 21st Century, 7th ed. (Calgary: Canadian Centre for Energy Information, 2004) at 118.

78 ERCB, Directive 065: Resources Applications for Conventional Oil and Gas Reservoirs (Calgary: ERCB, 2008) [Directive 065]; see EUB, Commingled Production in Development Entities and Water Surveillance (October 2006), online: ERCB <http://www.ercb.ca/docs/documents/commingling/ Des_Water SurveillancePresentation200610.pdf $>$.

79 See ERCB, “Management of Commingling in the Wellbore,” online: ERCB <http://www.ercb.ca/portal/ server.pt/gateway/PTARGS_6_0_308_0_0_43/http\%3B/ercbContent/publishedcontent/publish/ercb _home/industry_zone/rules_regulations_requirements/management_of_commingling_in_the_wellbo re/>.

80 EUB, Self-Declared Commingling (December 2006) at 14, online: ERCB <http://www.ercb.ca/ ocs/documents/commingling/Self_Declared_Presentation200612.pdf>.

81 ERCB, Directive 062: Coalbed Methane Control Well Requirements and Related Matters (Calgary: ERCB, 2010).

$82 \quad$ Self-Declared Commingling, supra note 80 at 8-12. 
SD commingling of oil or gas pools is permitted without an application under Directive 065 where the potential for enhanced recovery is less than an average of three $\mathrm{m}^{3} /$ day over the past three months. ${ }^{83}$ In all cases there must be an annual pressure test on the well to ensure that recovery does not violate Directive 065. The changes to SD and DE are designed to clarify the acceptable commingling practices and reduce the number of disputes when there is commingling, as they are designed to increase certainty in regard to the dimensions of shallow pools. Under the SRR regime it is unclear as to how commingling will be managed in what is a more complicated situation due to an increase in the number of zones from which production is to occur.

When there is production from multiple zones in one well and no spinner test is completed, the volume of production from each zone can be unclear. ${ }^{84}$ In this type of situation we anticipate disputes amongst the mineral rights holders.

\section{A. Consolidation of Agreements}

In regard to the consolidation of agreements, as of 22 March 2010 Alberta Energy has made policy changes regarding the consolidation of P\&NG agreements. Previously, "consolidation was limited to the areal extent of agreements." ${ }^{85}$ Now consolidation will be considered for approval by Alberta Energy in the case of both areal and stacked agreements. $^{86}$ The requirements listed by Alberta Energy for consolidation of two or more stacked agreements include the following: "they must be in the same term, be for the same substance(s), have identical surface access restrictions, not be contained within a Unit agreement, have the same designated representative, have lessees with equal interests in all agreements, and be contiguous rights." ${ }^{87}$ Alberta Energy will not approve the consolidation of licences in their initial term. ${ }^{88}$ To consider consolidation of agreements "[i]n their primary or intermediate term," Alberta Energy has indicated that the "request letter must be received in the department prior to expiry of each agreement included in the request." ${ }^{89}$ If the consolidation request pertains to an agreement for which the shallow rights reversion notice has been issued, Alberta Energy has stated that "the request letter must be received in the department prior to expiry of the notice of each agreement included in the request."

\section{TRESPASS}

As the SRR regime should promote more drilling and production from additional zones, there is increased potential for trespass actions of the type found in Xerex, discussed in Part II, above. ${ }^{91}$ Section 54(1) of the MMA provides that “[n]o person shall win, work or recover

83 Ibid. at 25.

See ERCB, "Well Testing,” online: ERCB <http://www.ercb.ca/portal/server.pt/gateway/PTARGS_0 _240_2587709_0_0_18/>; Schlumberger, “Oilfield Glossary: spinner flowmeter,” online: Schlumberger <http://www.glossary.oilfield.slb.com/Display.cfm?Term=spinner\%20flowmeter>; Directive 065, supra note 78. The ERCB revised Directive 065 on 10 August 2010, after the writing of this article.

85 Alberta Energy, Information Letter 2010-10, “Consolidation of Petroleum \& Natural Gas (P\&NG) Agreements" (22 March 2010) at 1.

Ibid.

Ibid.

Ibid.

Ibid. at 2.

Ibid.

Supra note 30. 
a mineral that is the property of the Crown in right of Alberta unless the person is authorized to do so under this Act or by an agreement." ${ }^{22}$ Section 58 of the MMA allows licensees to drill through zones other than their own to test their rights held under a Crown agreement. ${ }^{93}$

Circumstances that can constitute trespass on Crown lands include "[d]rilling, testing or terminating a well in, or producing from: a) rights that have expired and have been severed from an agreement, b) undisposed Crown mineral rights, and c) rights within road allowances," without permission to do these activities from the relevant government authority. ${ }^{94}$ Licensees generally have a $15 \mathrm{~m}$ over-hole allowance to drill into undisposed Crown minerals in order to accommodate drilling tools, and it is a trespass to drill beyond the $15 \mathrm{~m}$ zone. ${ }^{95}$ The misinterpretation of ZD or DRRZD can also amount to a trespass. ${ }^{96}$

In the event that a licensee trespasses on Crown minerals, it is recommended that the licensee stop the activity and inform the Manager of Crown Equity at Alberta Energy, as well as the ERCB. ${ }^{97}$ The company must be prepared to release all data related to the trespass. ${ }^{98}$ The consequences for trespass include a pecuniary penalty of $\$ 50,000$ for each trespass under s. 54 of the $M M A .{ }^{99}$ The ERCB can prohibit further disposition of the parcel until the ERCB is satisfied that all relevant information of the trespass has been reported. ${ }^{100}$ Under s. $63(1)$ of the $M M A$, the Crown can prosecute the trespasser and, upon summary conviction, the trespasser will face a fine of up to $\$ 100,000$. As of 1 November 2005, compensation costs are no longer allowed in cases of trespass. ${ }^{101}$

With increased emphasis on the development of shallow gas zones, hydraulic fracturing may become more frequent in Alberta CBM development, as it has in the U.S., and prompt trespass disputes. In Coastal Oil \& Gas v. Garza Energy Trust, ${ }^{102}$ royalty interest owners of a natural gas lease sued the gas well operator for subsurface trespass, breach of the duty to pool in good faith, and breach of implied covenants to develop, protect, and manage the lease.

The predecessor to Coastal Oil \& Gas Corp. (Coastal Oil) had engaged in hydraulic fracturing with permission from the relevant authorities. During the injection process, Coastal Oil fractured rock in an adjacent parcel on land where there were different royalty owners and subsequently captured natural gas from the other lease. The royalty owners sued and were successful in the trial court and in the Texas Court of Appeals. ${ }^{103}$ However, the Supreme Court of Texas ${ }^{104}$ held that Coastal Oil had not committed the tort of trespass in

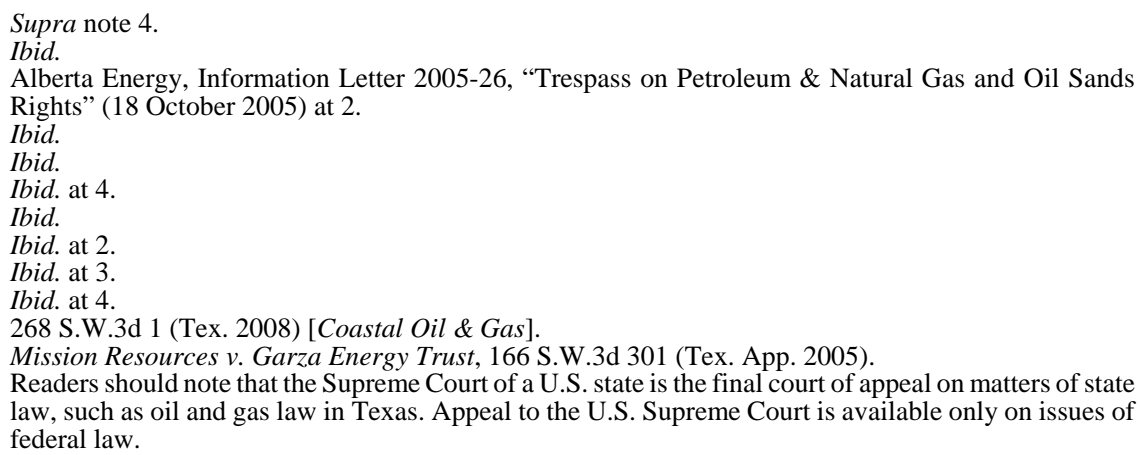
law, such as oil and gas law in Texas. Appeal to the U.S. Supreme Court is available only on issues of federal law. 
recovering the minerals from the adjacent lease. ${ }^{105}$ To hold otherwise, the Court would have changed the rule of capture, which gives a mineral interest owner title to all lawfully produced oil or gas. ${ }^{106}$ Such a change would have opened the door to litigation regarding hydraulic fracturing and created uncertainty in an important sector of the Texas economy. However, the holding expressly declined to state whether or not hydraulic fracturing generally could give rise to a claim of trespass. ${ }^{107}$ Notwithstanding the difference in the approach to the rule of capture under Alberta law, Crown lessees should be aware that claims for trespass on Crown minerals from different zones may well increase with the growth in hydraulic fracturing to produce shallow gas from multiple zones by different companies.

\section{FREEHOLD LANDS}

Unlike Crown minerals, oil and gas on freehold lands are not subject to reversion of the deeper or shallower rights at the termination of the primary term unless provided for by a clause in a freehold oil and gas lease. ${ }^{108}$ In 1999, CAPL and the Natural Resources Section of the Canadian Bar Association formed a joint committee that recommended that the model freehold lease include the reversion of deeper formations. However, the CAPL 1999 Alberta Petroleum and Natural Gas Lease did not incorporate the reversion provision for DRR on freehold lands. ${ }^{109}$ John Ballem has noted that a clause requiring the lessee to surrender deeper rights could take the following form if it were included in the habendum clause of a freehold lease:

PROVIDED that if at the end of the primary term the said lands or any lands with which the said lands are pooled or unitized are capable of commercial production, the lessee shall surrender all formations within the said lands which lie below the base of the deepest formation which is capable of production, except that if any operation contemplated in clause $1(\mathrm{~g})(\mathrm{i})$ is being conducted at the end of the primary term then the date of such surrender shall be extended to 90 days after cessation of such operation. ${ }^{110}$

As a clause for the reversion of deep rights in freehold leases has not been widely adopted in industry to date, it is unclear whether there will be action to provide for reversion of shallow rights on freehold lands. However, as the motivation of the Alberta government is to optimize oil and gas revenues, the SRR regime may prompt freehold mineral rights owners to likewise seek additional revenue from the development of shallow oil and gas zones.

\section{MINERAL RIGHTS EXPROPRIATION WITHOUT COMPENSATION?}

Counsel contemplating an expropriation claim under the North American Free Trade Agreement Between the Government of Canada, the Government of Mexico and the

See Coastal Oil \& Gas, supra note 102.

Ibid. at 13.

Daniel M. McClure, William D. Wood \& Robert S. Ballentine, "Texas Supreme Court Decision in Coastal v. Garza: Rule of Capture Bars Recovery of Drainage Damages for Subsurface Trespass from Hydralic Fracturing” Energy Litigation (3 September 2008) at 1, online: Fulbright \& Jaworski LLP $<$ http://www.fulbright.com/images/publications/ALERTTexasSupremeCourtDecisioninCoastalvGar za1.pdf>.

Freehold Owners Association, supra note 10.

Ibid.

John Bishop Ballem, The Oil and Gas Lease in Canada, 4th ed. (Toronto: University of Toronto Press, 2008) at 171 [emphasis in original]. 
Government of the United States ${ }^{111}$ in response to the SRR regime should consider the outcome of the 2009 tribunal decision in Glamis Gold Ltd. v. United States. ${ }^{112}$ The decision is the first mineral regulatory takings dispute under NAFTA in which a tribunal has considered whether compensation was warranted for an alleged expropriation arising from the frustration of reasonable investment-backed expectations of a mineral developer. There are very few previous cases considering takings under arts. 1110 and 1105 of NAFTA, and none dealing with the expropriation of mineral rights. The broad language in Chapter 11 of NAFTA, which defines expropriation, can support numerous interpretations, and compounds the uncertainty surrounding the meaning of the trade agreement provisions. ${ }^{113}$

Some provisions in NAFTA were intended to provide protection to investors from discriminatory treatment by a host government where the investment is made. ${ }^{114}$ NAFTA affords foreign investors with broad substantive rights to pursue a regulatory takings claim before an international tribunal. Chapter 11 provides mineral developers, as investors, with the right to seek takings compensation from a national government. Article 1110 of NAFTA provides that

[n]o Party may directly or indirectly nationalize or expropriate an investment of an investor of another Party in its territory or take a measure tantamount to nationalization or expropriation of such an investment ... except:

(a) for a public purpose;

(b) on a non-discriminatory basis;

(c) in accordance with due process of law and Article 1105(1); and

(d) on payment of compensation in accordance with paragraphs 2 through $6 .^{115}$

Under NAFTA, the host government is to pay compensation for any measure that expropriates, or is tantamount to expropriation of, an investment of an investor of another signatory state. ${ }^{116}$ As was decided in a NAFTA tribunal decision in 2002, the term "investment" is defined broadly in art. 1139 of NAFTA to include "almost every type of financial interest." "117 The term "investment” includes "real estate or other property, tangible and intangible, acquired in the expectation or used for the purpose of economic benefit or other business purposes.”118 Glamis Gold, "Award" (8 June 2009), online: NAFTA Claims <http://www.naftalaw.org/Disputes/ USA/Glamis/Glamis-USA-Award.pdf> [Glamis Gold, "Award”].

113 Glamis Gold, "Reply Memorial of Claimant Glamis Gold Ltd." (15 December 2006) at 7, online: NAFTA Claims <http://www.naftalaw.org/Disputes/USA/Glamis/Glamis-USA-Reply.pdf>. NAFTA, supra note 111, arts. 605, 1124.

Ibid.

Ibid.

Feldman v. Mexico (2003), 42 I.L.M. 625 at 644 (International Centre for Settlement of Investment Disputes).

NAFTA, supra note 111 , art. 1139. 
After spending \$15 million on exploration and development of a deposit on federal lands in California, Glamis Gold Ltd. (Glamis), a Canadian mineral developer, claimed \$50 million in compensation for an expropriation under Chapter 11 of NAFTA. The company learned about a proposed land withdrawal for environmental protection that might affect mineral production on its property, and company representatives questioned the Bureau of Land Management (BLM), as the federal land regulator, about whether the proposed land withdrawal would impact production from its mineral deposit. ${ }^{119}$ The Glamis President and CEO reported that at a meeting with the BLM State Director he "assured me that the [project] eventually would be approved ... but that we would have to be patient for a while longer." 120 The mineral developer asserted that both the U.S. government and the company understood that under U.S. law "there was no lawful basis to deny the plan of operation" for the project. $^{121}$

In addition, counsel for the company submitted that once it appeared that the federal government was taking steps to remove the obstacles preventing the project from being approved, the California government took matters into its own hands and "simply changed the law in an unprecedented manner to prohibit any cost-effective operation" of the property. ${ }^{122}$ To support the mineral rights expropriation claim, counsel submitted that the California government's actions were "clearly discriminatory and targeted at [the property]," ${ }^{23}$ and cited the following statement made by the proponents of the offending California Bill:

[the mine needed] to be made operative immediately because of provisions that establish new reclamation requirements.... These changes to [the] statute are urgently needed to stop the Glamis Imperial mining project.

The author believes the back-filling requirements established [by the bill] make the Glamis Imperial project infeasible. $^{124}$

The Governor's Office of Planning and Research also stated that the bill would "permanently prevent the approval of the Glamis Gold mine," which the Office acknowledged would have otherwise been approved. ${ }^{125}$

Glamis Gold, “Memorial of Claimant Glamis Gold Ltd.” (5 May 2006) at paras. 259-60, online: NAFTA Claims <http://www.naftalaw.org/Disputes/USA/Glamis/Glamis-Memorial-Claimant.pdf> [Glamis Gold, "Memorial of Glamis Gold”].

Ibid. at para. 260.

Glamis Gold, "Redacted Transcript, Day 1: Oral argument of Mr. Gourley, Counsel for Glamis” (12 August 2007) at 52, online: NAFTA Claims <http://www.naftalaw.org/Disputes/USA/Glamis/GlamisTranscript-Day01.pdf> [Glamis Gold, "Oral argument of Mr. Gourley”].

Glamis Gold, “Memorial of Glamis Gold,” supra note 119 at para. 552.

Glamis Gold, “Oral argument of Mr. Gourley,” supra note 121 at 67.

Glamis Gold, "Memorial of Glamis Gold,” supra note 119 at para. 372 [emphasis omitted], citing U.S., Bill Analysis: Hearing on SB 22 Before the Senate Committee on Natural Resources and Wildlife (14 January 2002), online: California State Senate <http://info.sen.ca.gov/pub/03-04/bill/sen/sb-00010050/sb_22_cfa_20030110_115605_sen_comm.html >.

Glamis Gold, "Memorial of Glamis Gold,” $i b i d$. at para. 374 [emphasis omitted], citing U.S., California Governor's Office of Planning and Research, Enrolled Bill Report of SB 22 (California: Governor's Office of Planning and Research, 2003) at 1. 
The NAFTA Tribunal considered "(1) the extent to which the measures interfered with the reasonable and investment-backed expectations of a stable regulatory framework, and (2) the purpose and character of the governmental actions taken.”126 The Tribunal held that before embarking on the above two-step analysis, the Tribunal must ask a "threshold question" to analyze "the degree of interference with the property right" in order to determine whether the government action "is sufficient to potentially constitute a taking at all."127 Analysis of the degree to which the relevant government action interfered with the mineral property rights was broken down further into two additional components: "the severity of the economic impact and the duration of that impact." ${ }^{128}$ Before analyzing the reasonableness or purpose of the government measures, the Tribunal sought to "determine whether [the] Claimant's investment in the ... Project has been so radically deprived of its economic value ... as to potentially constitute an expropriation." ${ }^{29}$ The Tribunal required the company to prove that its mineral rights were essentially "useless" and not merely restricted ${ }^{130}$ and concluded that as the company did not satisfy the threshold requirement, no compensation was warranted.

Notwithstanding continuing uncertainty in the area of regulatory takings compensation under NAFTA, the fact that the international tribunal decisions are not binding, and in light of the decision in the Glamis Gold, as the SRR regime does not completely deprive mineral rights holders of the entire value of Crown oil and gas leases, nor is the SRR regime targeted toward a single project, we submit that it is unlikely that an expropriation claim would be successful based on the impact of SRR on Crown lessee rights.

\section{Cumulative EnVIRONMENTAL EFFECTS}

SRR is intended to encourage the development of marginal shallow gas plays. In some unconventional gas fields a much larger number of CBM wells ${ }^{131}$ are required to produce the equivalent volume of natural gas that would be produced from one well in a conventional reservoir. We anticipate a larger surface footprint due to the increased number of wells to be drilled under the SRR regime. However, the ERCB encourages joint use of roads and facilities and the use of common well-pads to mitigate some of the environmental impacts. It is unclear what the cumulative effects will be from shallow gas development in multiple zones under SRR, and how the Alberta government will address these effects under the Alberta Land Stewardship Act. ${ }^{132}$

\section{UNANSWERED QUESTIONS}

In situations in which one company holds the mineral rights to multiple zones on the same piece of land, the question can arise: what is the appropriate method for reporting acreage to investors and securities regulators? If the acreage covered by multiple leases for all zones is combined, a much larger acreage may be reported by an oil and gas producer, which could

Glamis Gold, “Award,” supra note 112 at para. 356 [footnotes omitted].

Ibid. at paras. 356-57.

Ibid. at para. 356.

Ibid. at para. 358.

Ibid. at para. 357, citing OECD, “Indirect Expropriation" and the "Right to Regulate" in International Investment Law, Working Papers on International Investment, No. 2004/4 (2004) at 11.

Sometimes four to eight.

S.A. 2009, c. A-26.8. 
be misleading to investors. A second question that can be posed is: will existing computerized systems accurately reflect both the acreage and the reserves for multiple zones? Some of the other questions to consider include the following: what are the implications of SRR for unitization? Specifically, how will the Alberta government manage commingling issues? In some situations, production from deeper zones requires higher operating pressures than in shallower zones, and common production streams may not be feasible. Will SRR prompt more common carrier and processor applications from shallow gas developers and disputes? Which criteria will the Minister of Energy use to determine whether an extension is granted? In light of the anticipated increase in the number of wells to be drilled to test and develop shallow zones, what will be the local, regional, and cumulative environmental impacts arising from the adoption of the shallow rights regime? Other types of energy development projects, such as the Swan Hills Synfuels coal gasification project, are on the horizon. ${ }^{133}$ In light of the potential for methane migration from coal gasification plants toward shallower zones in closer proximity to the land surface, what potential disputes may arise?

\section{ConClusion}

The more sophisticated SRR scheme adopted to increase the level of shallow gas exploration and production on Crown lands is an extension of the DRR regime that has existed in Alberta for decades. Section 82 of the MMA provides for the shallow rights to revert to the Crown when there is no production. In April 2011, the Alberta government will start serving notices on Crown mineral agreement holders about the reversion of their rights to shallow zones. The Alberta government will provide a three-year notice period to existing Crown mineral lessees. Notices will be served on a vintage basis throughout future years that identify the shallowest productive zone, as determined by Alberta Energy based on public records. If the identified shallow zone is not drilled or tested to facilitate production it can revert to the Crown. The increased complexity and uncertainty under SRR may prompt disputes and litigation. In response to the emerging SRR system, some oil and gas developers are in the process of reviewing existing agreements, and considering consolidations.

In light of the language in Crown oil and gas leases and the 2009 NAFTA Tribunal decision in Glamis Gold, it is likely that expropriation claims of Crown lessees based on the trade agreement, in response to SRR, will fail. This analysis underscores the importance of the Alberta government clarifying the uncertainty surrounding the issues that we have identified. The lack of clarity regarding the rights to oil and gas located between zone designations in Alberta, the implications of SRR for commingling and unitization, and the potential for trespass actions are some of the issues that merit further consideration. 